\title{
Some new North American plants. I.
}

\section{JOHN M. COULTER AND E. M. FISHER.}

Heuchera Hapemani, n.sp. Stem short and slender (10 to $22 \mathrm{~cm}$. high), densely glandular above, with rather few leaves, from a slender running rootstock: leaves (both radical and cauline) round-reniform ( 3 to $3.5 \mathrm{~cm}$. broad), thin, glabrous, deeply 7 to 9 lobed (lobes dentate, with a linear gland in the sinuses), on slender grooved petioles: panicle loose and racemose; bracts and bractlets small and foliaceous: flowers on pedicels much shorter than the calyx, which is turbinate, 4 to $5 \mathrm{~mm}$. long, the thin acute lobes one-third as long as the ovary: petals white (often purplish), entire, short clawed, 3 $\mathrm{mm}$. long: stamens included, with very small anthers. -Big Horn Mountains, Wyoming, Dr. H. Hapeman, who says "the plants grew at the base of a cliff, near the water, in dark places. They follow the cracks in the rock by a slender running rootstocks." The species belongs to the group containing $H$. Hallii, but its leafy stem, deeply lobed and dentate (neither bristly nor ciliate) reniform leaves, narrower and pointed calyx-lobes, much longer and ovate short clawed petals, and its very small stamens, are characters which distinctly separate it.

BOERHAAVIA ANISOPHylla Gray, var. paniculata n. var. - As compared with the type, this plant has larger and very diffuse panicles, smaller flowers mostly solitary at the extremity of the branchlets, calyx pubescent along the ribs, and purplish pubescent fruit ( $4 \mathrm{~mm}$. long) rugose between the ribs.Chenate Mountains (Nealley 405).

Abronia Suksdorfii, n. sp. - More or less viscid-pubescent: stem erect, $4 \mathrm{dm}$. high from a perennial base: leaves obtuse, elliptical-ovate or oblong-oval, slightly rounded at base: peduncles 8 to $15 \mathrm{~cm}$. long (twice longer than the leaves): bracts 5 , white-scarious, linear-lanceolate $(8 \mathrm{~mm}$. long), acute, subtending 8 to 16 slender flowers: perianth greenish-white, the lobes obcordate: fruit indurated, broader than long, with 5 broad wings which are neither reticulated nor crested.Sandy grounds near Columbus, Klickitat Co., Washington, June II, 1886, W. N. Suksdorf. Distributed as A. mellifera Dougl. The species cannot be grouped with $A$. mellifera, as the wings are double and very coriaceous. The relationship 
is nearest to $A$. fragrans, but the narrow involucral bracts and the broader and more coriaceous wing, with no reticulations, seem well to separate it.

Abronia Carletoni, n. sp.-Stems procumbent, slender, whitish, minutely glandular, 2.5 to $4 \mathrm{dm}$. long: leaves very thick, linear-oblong or oblong-ovate, with cuneate base and revolute margins: peduncles very slender, as long as the leaves: involucral bracts 5, rose-color, oblong-lanceolate, attenuate or cuspidate, $6 \mathrm{~mm}$. long: flowers numerous: perianth rosecolor, with obcordate lobes: fruit longer than broad, scarcely coriaceous, with the 5 wings coarsely reticulated and terminating above in disks.-E. Colorado, Prof. M. A. Carleton 459, I891. Most closely related to A. turbinata Torr., having the coriaceous double wing of the'section, but differing from that species in having slender white glabrous (but minutely glandular) stems, more numerous flowers, broader rose-colored attenuate or cuspidate bracts, and the perianth and its lobes not so deeply cut.

Gomphrena Pringlei, n. sp.-Low, procumbent, strigosepubescent, from a long filiform root: stems many, rose-color, di- or trichotomously branched, 5 to $7 \mathrm{~cm}$. long: leaves halfclasping, oblong-lanceolate, mucronulate, I-nerved, I to I. 5 $\mathrm{cm}$. long: heads many, globose, dense, white (slightly rosetinted), 5 to $8 \mathrm{~mm}$. long, subtended by 3 or 4 leaves; the denticulate long-acuminate bracts equalling the keeled and broadly crested (dentate) acute bractlets: sepals woolly, cleft to near the base (the segments linear, acute), shorter than the bractlet: stamen-tube united to the top, with linear-oblong exserted anthers: stigmas 2, recurved, together with ovary and style equalling the stamen-tube.-Pringle 3152 , of the state of Mexico, distributed as $G$. decumbens Jacq. Very different from any described Gomphrena. The flowers and bractlets are somewhat similar to those of G. tuberifera, while the very short and procumbent branches seem to relate it to $G$. decumbens.

Gomphrena Nealleyi, n. sp.-Ascending, 14 to $20 \mathrm{~cm}$. high, loosely long-villous, from a fusiform root: leaves spatulate, mucronulate, glabrate above, half-clasping, 3 to $3.5 \mathrm{~cm}$. long; the upper ovate and much smaller: peduncle terminal, about 9 to I $\mathrm{cm}$. long: heads rose-tinted, sessile, dense, oblongobovate, $2 \mathrm{~cm}$. or more long, subtended by two larger leaves: 
flowers $5 \mathrm{~mm}$. long: bracts ovate, acute, half as long as the keeled and slightly crested acute bractlets: sepals linear-lanceolate, slightly cleft, densely woolly below, little shorter than the bractlets: stamen-tube united to the top, with linear-oblong exserted anthers: stigmas, 2, minute, spreading.-Corpus Christi, Texas. Nealley 420, referred to $G$. nitida Roth. in Contr. Nat. Herb. I. 48. In general appearance this species simulates $G$. decumbens, but the subsessile stigmas place it in an entirely different section.

Frolichia Texana, n. sp.- Erect, silky-villous, $5 \mathrm{dm}$. or more high, sparingly branched from a perennial base: leaves usually obtuse and mucronate, farinose, whitish and densely silky below; the radical spatulate, 8 to $9 \mathrm{~cm}$ long, tapering to a slender petiole; the cauline short-petioled or subsessile, oblong or elliptical-ovate, 2.5 to $3.5 \mathrm{~cm}$. long: peduncles terminal, the spikes $3 \mathrm{~cm}$. long, lengthening and becoming scattered in age: flowers $5 \mathrm{~mm}$. long, with thin bracts and bractlets, the latter very broad and deeply concave : fruiting calyx fuscous, cordate, flat on one side, the wings pale, broad, crenate.-Pena, Western Texas. Nealley 521 , referred to $F$. Floridana Moq. in Contr. Nat. Herb. I. 48. The species most nearly resembles F. Floridana, but differs in its elliptical-ovate leaves, very broad and deeply curved bractlets, and cordate fruiting calyx (flat on one side) with pale crenate wings.

Eriogonum Texanum, n. sp. - A stout subtomentose perennial, about $6 \mathrm{dm}$. high, simple, woody below, naked above: leaves very coriaceous, linear-lanceolate, 7 to $10 \mathrm{~cm}$. long, tapering below to a short clasping petiole, densely tomentose beneath, silky-villous above: inflorescence twice or thrice di- or trichotomous, with divaricate branches: involucre solitary, sessile, coriaceous, 5 to $7 \mathrm{~mm}$. long, with five short and round teeth: flowers yellowish, on long pedicels, densely silky-villous, 7 to $8 \mathrm{~mm}$. long: perianth segments similar, oblong-lanceolate, thickish, with rugose margins. -W. Texas, Nealley, 1890. This species belongs to $\$$ OREGONIUM, and seems to be unlike all others in the very coriaceous texture of the leaves and inflorescence, the former with a very prominent midrib. The very thick involucre is strongly nerved (as seen within), its teeth tipped with a short mucro, and the central ones are short pedunculate. 
Eriogonum Pringlei, n. sp.-Woody, $3 \mathrm{dm}$. high, densely white tomentose, leafy throughout, with flaky bark, and many slender intricate branches above, each terminated by a loose paniculate spike ( 4 to $6 \mathrm{~cm}$. long), leaves linear, acute, very small (I $\mathrm{cm}$. long, ) narrower toward the base, strongly revolute, often with smaller ones fascicled at the base of the branchlets: bracts very small, triangular to setaceous: involucres sessile, small ( $2 \mathrm{~cm}$. long), 6 to 9, regularly distributed, each containing 4 or 5 minute whitish or slightly rosecolored flowers ( $2 \mathrm{~mm}$. long). - Rocky hills near Maricopa, Arizona, Pringle, in 1882 , and distributed as " $E$. Wrightii Torr., var., or a new species." It is nearest to E. Wrightii Torr., but its flaky bark, many intricate branchlets, short linear revolute leaves, numerous spikelets with smaller and regularly arranged involucres and flowers, narrower and lighter colored sepals, and smooth achenes make it a very distinct species.

Euphorbia Nealleyi, n. sp.--Densely puberulent throughout; stems slender, erect or ascending ( 2 to $3 \mathrm{dm}$. high), branched or simple at the woody base, with few alternate branches above: leaves opposite, linear, $(2$ to $3 \mathrm{~cm}$. long, I to I. $5 \mathrm{~mm}$. wide), entire, short-petioled, thickish, acute, cuspidate; glandular stipules minute: involucres solitary, axillary and terminal, pedunculate, turbinate; glands 4 , transversely oblong, with large and white irregularly dentate truncate appendages: style short: pod rather depressed, about $3 \mathrm{~mm}$. broad: seed ovate-triangular, deeply and irregularly transverse sulcate.-W. Texas (Nealley, I 890). This species belongs to $\$$ ALECTEROCTONUM except the leaves are simply opposite and not ternate or verticillate. Its general appearance is that of E. biformis Watson, but its stems are alternately branched and its seeds are strongly sulcate. It really seems to be somewhat intermediate between the sections Alecteroctonum and Zygophyllidium.

Ricinella Vaseyi (Coulter.) Euphorbia Vaseyi Coulter, Contr. U. S. Nat. Herb. I, 48. Since the publication of this species additional material and information have come to hand, which make it evident that it must be referred to Ricinella (Adelia.) In addition to the characters given in the contribution referred to the following may be added: The plant is a diœcious shrub, I 5 to $18 \mathrm{dm}$. high, with several 
straight branches from the root. The staminate flowers have five sepals and ten stamens, and fall off at once when touched. The species is most nearly related to the West Indian Ricinella pedunculosa Muell. (Adelia Ricinella), but its simple long stems (branched at base,) small coriaceous to three nerved narrowly obovate non-punctate leaves (not shining above), single and short ( $1.5 \mathrm{~cm}$.) fruiting pedicel, and much larger angulate seed with prominent hilum, make it a very dis. tinct species. From Brazos Santiago and Booneville, Texas (Nealley).

Sisyrinchium Thurowi, n. sp. Low ( 4 to $7 \mathrm{~cm}$. high), cespitose and procumbent: stems rather broadly winged, with a flower-bearing branch at each node: leaves short, scarcely $2 \mathrm{~mm}$. broad: corolla 4 to $5 \mathrm{~mm}$. long: outer bracts a little longer than the very slender pedicels: flowers small, yellow, 2 to 4 in each umbel: pods oblong or pear shaped ( 4 to $5 \mathrm{~mm}$. long), prominently transversely wrinkled between the seeds, which are IO to 14 in each cell, depressed-globose, very small (scarcely $0.5 \mathrm{~mm}$. broad), black and deeply punctate. -Hockley, Texas, Thurow. Nearest S. Schaffneri Wats., but smaller, densely cespitose and procumbent, not at all scapose (the stems bearing leaves and flowering branches), with smaller leaves, smaller, firmer and more deeply wrinkled pods, and very minute black punctate seeds.

Fritillaria linearis, n. sp. Bulb scales few and thick: stem 20 to $25 \mathrm{~cm}$. high: leaves (IO or more) narrowly linearlanceolate, scattered, more or less whorled below: flowers 2 , blotched with brownish purple within, $2 \mathrm{~cm}$. long, the segments ovate-lanceolate, slightly spreading at the tips, much longer than the style, which is deeply parted and much longer than the stamens. - Black Hills of Dakota. In some way the name of the collector has been lost. The species is nearest $F$. biflora, but is much lower, leafy throughout with linear leaves, ovate-lanceolate lighter colored perianth segments, and much smaller stamens on filaments much shorter than the deeply parted styles.

Indiana University, Bloomington. 


\section{$2 \mathrm{BHL}$ Biodiversity Heritage Library}

Coulter, John Merle and Fisher, Elmon McLean. 1892. "Some New North American Plants. I." Botanical gazette 17(11), 348-352.

https://doi.org/10.1086/326857.

View This Item Online: https://www.biodiversitylibrary.org/item/92733

DOI: https://doi.org/10.1086/326857

Permalink: https://www.biodiversitylibrary.org/partpdf/222197.

\section{Holding Institution}

Missouri Botanical Garden, Peter H. Raven Library

\section{Sponsored by}

Missouri Botanical Garden

\section{Copyright \& Reuse}

Copyright Status: Public domain. The BHL considers that this work is no longer under copyright protection.

This document was created from content at the Biodiversity Heritage Library, the world's largest open access digital library for biodiversity literature and archives. Visit BHL at https://www.biodiversitylibrary.org. 